The B.M.A. and our Negotiating Committee would do well for the future of the profession and the health of the country if they gave this question of hours and conditions of work their sympathetic consideration and did not regard the vote at the A.R.M. as final. If there is any doubt on this point it would be enlightening to have an "expression of opinion" on the subject from the silent rank and file of the profession.

There is another matter which may be mentioned here-the abolition of the basic petrol ration. We are to be subjected to the questioning of the police, who are only doing their duty, on our comings and goings, and should we wander ever so slightly out of our "beat" are likely to be run in for breaking the law. We, I am sure, have no desire to claim any special consideration in the present difficult state of the country, but it would be well to remember that it was the last straw that finished the camel. -I am, etc.,

Birmingham.

Dispensers in N.H.S.

W. Duane.

SIR,-I should be grateful if someone could answer the question as to what in the coming national medical service is to become of the medical practitioner's dispenser who possesses the Apothecaries Hall certificate. We in our practices know the value of these good people. According to the advertisements in the British Medical Journal an individual so qualified is worth a salary of $\mathrm{f6}$ a week. Are these good people to be thrown out of a job at the last minute? Many of them have relatives dependent on them.

Some advice should surely be at hand as to whether they should continue, or branch into other spheres of activity. This will seem very hard after working hard to qualify for their certificate and perhaps having worked very diligently subsequently. I apologize for taking up this space in your columns ; but feel the need is just.-I am, etc.,

Colwyn Bay. Denbighshire.

Reginald R. Halsall.

\section{Shaping Things to Come}

SIR,-Put bluntly the so-called Representative Meeting of the B.M.A. was a sorry affair if one's reading of the facts is correct. The peculiar City motion that "the inclusion of women and children in a twenty-four-hour service will throw a heavy strain on doctors under the Act," etc., was actually discussed before Dr. E. B. Smith pointed out how singularly ill chosen was the wording. Many of the " Representatives" represented nothing more than their own myopic and selfish viewpoint and not the views of the doctors in their Division. The constructive and sensible motion by Dr. G. de Swift for a rota of practitioners was defeated by men who certainly did not represent the views of the solo G.P. or those working in rural districts. Instead they asked, What is wrong with a partnership? Those whose partnership is self-sufficient and who intend to remain outside the new Service should refrain from shaping that Service.

Thanks to the muddled thinking of the profession, the confused wording of the B.M.A. plebiscite, and the flank attack by the three wise Presidents of Gotham, we have already put our heads in the noose and are now squealing about the secrecy of the negotiations. Will we never learn, or are the events in dictator countries still too recent for us to see them in correct perspective and grasp the implications they hold for us at this moment? Having unwittingly betrayed our patients, are we now to betray those G.P.s entering the new Service, or are we to help in shaping it constructively to our own satisfaction?

It must be obvious that had the Government's sole desire been a better health service they could have included the wives, children, and dependants of the present insured class for a start, and taken over the major financial responsibilities of the voluntary hospitals. But patients are to be nationalized in toto, and those G.P.s who join the Service are expected to give up the goodwill of their practices, with compensation-like our post-war credits- to be paid on death or retirement. Do we get interest meanwhile ? If so, will it be a paltry Government $2 \frac{3}{4} \%$ while we continue to pay 4 or $5 \%$ on our mortgages ?

Let us at least see what advantages there could be in a complete State service for the G.P. to compensate for the grave loss of independence. Having served for six years in one of the finest of the State medical services (the Navy) one can visualize a civilian State service. From the G.P.'s viewpoint his income will probably drop considerably, but so should his expenses, as he will no longer own his practice, and therefore (1) his house will cease to be a public house for 24 hours a day. He will ultimately work at a clinic, and will be able to live in a smaller house out of the neigh- bourhood if he wishes, as do M.O.H.s. (2) Until clinics are built the Government should rent his surgeries from him. (3) Muct needed clerical assistance for the group of doctors at a clinic should be provided (as in the Services). Meanwhile, the doctor's maid, wife acting as maid and clerical assistant, should be paid for bo the Government until clinics are built. (4) Having-no private praEtice, the State doctor should have a State car provided for him visit the State's patients-upkeep, petrol, and garage to be a Stace liability, of course. (5) Locums during leave, and assistants durin the winter, will become a State responsibility. (6) A rota of doctef should be arranged for those who wish, either centrally or pre ferably locally by mutual arrangement. Doctors will do the morning clinics and their daily round. After that they would $b$ free, late calls, tmergencies, and the evening surgery for odd cases being dealt with by the duty G.P. for the day (as in the Servicesor?

As doctors will no longer provide a day and night service fo $\vec{D}$ dispensing, the local chemists will have to form a rota, with on chemist on duty after working hours. Those patients with more money than sense who send late and still require their ow: doctor could pay for the privilege. There is no valid reason why doctors who give up their independence, which in solर practice means voluntary slavery at the dictate of conscience should not find a wider freedom when organized on a nationas basis. There is of course an alternative to the whole business- -4 a change of Government before this and other schemes rendeff the nation bankrupt.-I am, etc.,

Dereham, Norfolk.

E. Puddy. 음

Protection from Administrative Zeal

SIR,-In these highly administered days it is shocking to realize that a majority decision by plebiscite gives no absolute protection from administrative zeal. We can note with adde dismay that while preparations are being made for the dissip? tion of the spirit of the majority of the answerers to our plebi scite, no comparable preparations to conserve that spirit are evident.

Could we not counter the unfortunate effect of the ignoring of the plebiscite result by a measure protective against the corruption by power to which administrators are prone Surely our Branches and Divisions are too large to handl $\bar{\partial}$ any real resistance to dictation. Could not subdivisions bf actively organized in every locality? What but good coul $\$$ be done by the B.M.A.'s encouragement of doctors to mee locally without the formality inseparable from larger gathero ings?-I am, etc.,

Ruislip, Middlesex

Willoughby Clark.

\section{Association Notices}

\section{Branch and Division Meetings to be Held}

East Suffolk Division.-At the Lecture Hall. Electric House Lloyds Avenue, Ipswich, Thursday, Sept. 18. 8.15 p.m., Meeting Film: The Eariy Diagnosis of Acute Anterior Poliomyelitis." A discussion opened by Dr. Ronald Jones will follow. All medical practio tioners in the area of the Division are invited.

Winchester Division.-At Royal Hotel, Winchester, Wednesday Sept. 17, 9 p.m. Address by Mr. C. K. Vartan: Some Obstetricai Emergencies and their Treatment.

\section{TRADE UNION MEMBERSHIP}

The following is a list of local authorities which are under stood to require employees to be members of a trade $u$ wion or other organization:

County Borough Councils: Barnsley, Barrow-in-Furness Gateshead.

Metropolitan Borough Councils: Finsbury, Fulham, Hackney, Poplar, Tottenham.

Non-County Borough Councils : Dartford, Leyton, Radcliffe (limited to future appointments), Wallsend.

Urban District Councils : Denton, Droylsden, Houghton-le Spring, Huyton-with-Roby, Portslade, Redditch (restricted to new appointments), Stanley (Co. Durham), Tyldesley.

Scottish Burghs: Motherwell, Wishaw.

Correction.-The name of Dr. L. Z. Cosin was spelt incorrectly in the list of members of the Committee on Care and Treatment of Elderly and Infirm in the Supplement of Aug. 30 (p. 61). 